\title{
New Record of the Tassled Scorpion Fish, Scorpaenopsis oxycephala (Bleeker, 1849) (Order: Scorpaeniformes, Family: Scorpaenidae) from Visakhapatnam Coast, Indian Waters
}

\author{
Muddula Krishna Naranji*, Sujatha Kandula
}

Department of Marine Living Resources, Andhra University, Visakhapatnam-530003, Andhra Pradesh, India

*Corresponding author: Muddula Krishna Naranji, Department of Marine Living Resources, Andhra University, Visakhapatnam-530003, Andhra Pradesh, India, E-mail: krishna.muddu217@gmail.com

\begin{abstract}
Based on twenty two specimens of the Tassled Scorpion Fish, species of Scorpaenopsis oxycephala (Bleeker, 1849) (85-96 mm, TL) collected from the Visakhapatnam coastal waters, east coast of India, we described Scorpaenopsis oxycephala as the new record from Indian Ichthyofauna.This species mainly characterized by having 12 dorsal spines, preopercular with five spines; supraorbital tentacle long; scales present in the space between opercular spines naked; occipital very shallow; pectoral length 26.22 in percentage of standard length; pelvic fin ray length 22.05 in percentage of standard length. In the present study the diagnosis, remarks and a specimen photo are given.
\end{abstract}

Keywords: Tassled scorpion Fish; Scorpaenopsis oxycephala; Visakhapatnam coast; India
Received date: November 17, 2016

Accepted date: December 12, 2016

Published date: December 19, 2016

Citation: Naranji, M.K., et al. New Record of the Tassled Scorpion Fish, Scorpaenopsis oxycephala (Bleeker, 1849) (Order: Scorpaeniformes, Family: Scorpaenidae) from Visakhapatnam Coast, Indian Waters. (2016) J Marine Biol Aquacult 2(2): 1- 4.

DOI: $10.15436 / 2381-0750.16 .013$

\section{Introduction}

22 specimens of the Scorpion Fish genus Scorpaenopsis Heckel, 1839 collected from the Visakhapatnam coast $\left(17^{\circ} 44^{\prime} \mathrm{N}\right.$, $\left.83^{\circ} 23^{\prime} \mathrm{E}\right)$, eastern central Indian Ocean. The indo-Pacific Scorpion Fish genus Scorpaenopsis Heckel, 1839, now comprising 27 species, is characterized by having 12 dorsal spines, lacking palatal teeth and of black pigment between in the first and third dorsal fin spines, and head strongly compressed ${ }^{[1]}$. Fishes of the family Scorpaenidae are widely distributed, although in small numbers, along both coasts of India and are represented in most catches in the exploited near shore waters. Scorpaenid fishes are mostly small, but of characteristic appearance and usually easily recognisable. From the Visakhapatnam waters, only two species of Scorpaenopsis venosa and Scorpaenopsis rosea have been recognized from the south-east coast of India including the adjacent waters of Indian waters to date. Whereas, five species have been known from the Indian waters ${ }^{[2]}$. From Visakhapatnam coastal waters reported one species of Scorpaenopsis venos ${ }^{[3]}$.
Recently two species of Scorpaenopsis genus belong to the family Scorpaenidae recorded from Visakhapatnam coastal waters, east coast of India ${ }^{[4,5]}$. These three Scorpaenopsis species were revealed to be new to Indian Ocean, Scorpaenopsis oxycephala that has been widely distributed from the Indo-Pacific, however not yet in the east coast of India. We therefore, describe Scorpaenopsis oxycephala as the new record from Indian waters.

\section{Materials and Methods}

Twenty two specimens of the Tassled Scorpion Fish, species of Scorpaenopsis oxycephala (Bleeker, 1849), 89 - 174 $\mathrm{mm}$ TL were collected from Visakhapatnam coastal waters $\left(17^{\circ} 44^{\prime} \mathrm{N}, 8^{\circ} 23^{\prime} \mathrm{E}\right)$ India (Figure.1). Counts, measurements and terminology of head spines follow those of ${ }^{[6,7]}$. Superscriptions in the description mean the number of specimens used in counts 

and measurements.

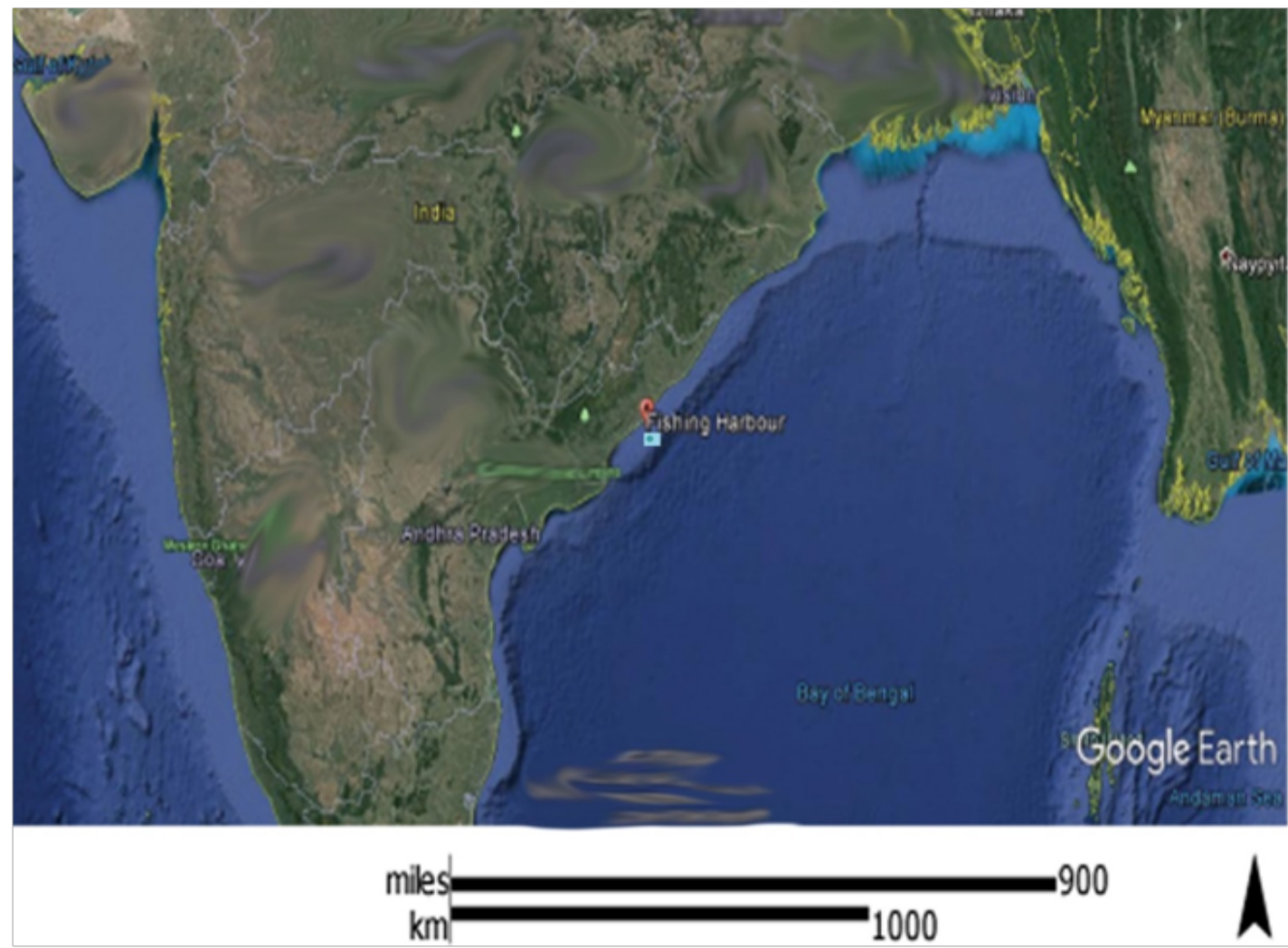

Figure 1: Figure showing study area and occurrence of Scorpaenopsisoxycephala from Visakhapatnam, India

\section{Results}

Systematics

Family Scorpenidae

Genus Scorpaenopsis Heckel

Species: Scorpaenopsis oxycephala (Bleeker, 1849)

(Figure 2a, b)

Description based on twenty two specimens (Figure 2a, b; Table-1)

Table-1: Morphometric data of the species of Scorpaenopsis oxycephala represented in the catches of Vishakhapatnam.

\begin{tabular}{|c|c|c|}
\hline \multirow{3}{*}{ Standard Length in mm SL } & \multirow{2}{*}{\multicolumn{2}{|c|}{$\begin{array}{c}\text { S. oxycephala, } n=22 \\
70-142\end{array}$}} \\
\hline & & \\
\hline & Min-Max & $\overline{\boldsymbol{X}} \pm \mathbf{S D}$ \\
\hline \multicolumn{3}{|c|}{ As percentage of standard length } \\
\hline Total length & $122.53-128.88$ & $125.26 \pm 1.95$ \\
\hline Body depth & $27.14-32.74$ & $30.35 \pm 1.79$ \\
\hline Head length & $40.14-47.19$ & $43.76 \pm 1.91$ \\
\hline Pre dorsal distance & $33.80-41.30$ & $37.76 \pm 1.93$ \\
\hline Pre pectoral distance & $38.57-44.56$ & $41.41 \pm 1.75$ \\
\hline Pre pelvic distance & $38.46-43.36$ & $41.16 \pm 1.42$ \\
\hline Pre anal distance & $71.66-79.34$ & $76.59 \pm 2.02$ \\
\hline Dorsal base & $55.55-61.94$ & $59.57 \pm 2.06$ \\
\hline Pectoral base & $12.74-16.66$ & $14.40 \pm 0.99$ \\
\hline Anal base & $12.67-16.66$ & $14.40 \pm 1.09$ \\
\hline Dorsal spine height & $10.61-16.04$ & $13.92 \pm 1.70$ \\
\hline
\end{tabular}

\begin{tabular}{|l|c|c|}
\hline Soft dorsal height & $12.90-20.22$ & $16.65 \pm 2.05$ \\
\hline Pectoral length & $22.54-30.00$ & $26.22 \pm 1.95$ \\
\hline Pelvic spine length & $10.56-14.81$ & $13.36 \pm 1.02$ \\
\hline Soft pelvic fin length & $19.60-25.00$ & $22.05 \pm 1.18$ \\
\hline Anal spine height & $16.90-23.33$ & $20.33 \pm 1.59$ \\
\hline Soft anal height & $18.30-24.69$ & $21.48 \pm 1.80$ \\
\hline As percentage of head length & \multicolumn{2}{|l|}{} \\
\hline Head depth & $53.33-60.41$ & $56.22 \pm 2.06$ \\
\hline Head width & $50.00-56.25$ & $53.0 \pm 2.09$ \\
\hline Eye diameter & $16.00-23.07$ & $18.70 \pm 1.85$ \\
\hline Pre orbital distance & $20.83-28.07$ & $23.80 \pm 1.65$ \\
\hline Post orbital distance & $46.66-55.76$ & $51.25 \pm 2.20$ \\
\hline Inter orbital distance & $13.33-20.00$ & $15.57 \pm 1.76$ \\
\hline Upper jaw length & $43.33-51.28$ & $47.85 \pm 2.22$ \\
\hline Lower jaw length & $40.00-46.15$ & $43.82 \pm 1.97$ \\
\hline Maxilla width & $15.78-19.23$ & $17.05 \pm 1.06$ \\
\hline Snout length & $20.58-28.94$ & $25.08 \pm 2.65$ \\
\hline Caudal peduncle depth & $08.33-12.35$ & $10.54 \pm 0.98$ \\
\hline
\end{tabular}

Scorpaenopsis oxycephala (Bleeker, 1849)

(Plate X, Figure. 2)

Tassled Scorpion Fish

Scorpaena oxycephalus Bleeker, 1849, Verh. Bat. Gen., 22 (5): 7. (Type locality: Indonesia).

Description based on 22 specimens measuring 89 - 174 mm TL (7J, 14 ㅇ \& $1 \overbrace{}^{\Uparrow})$. 


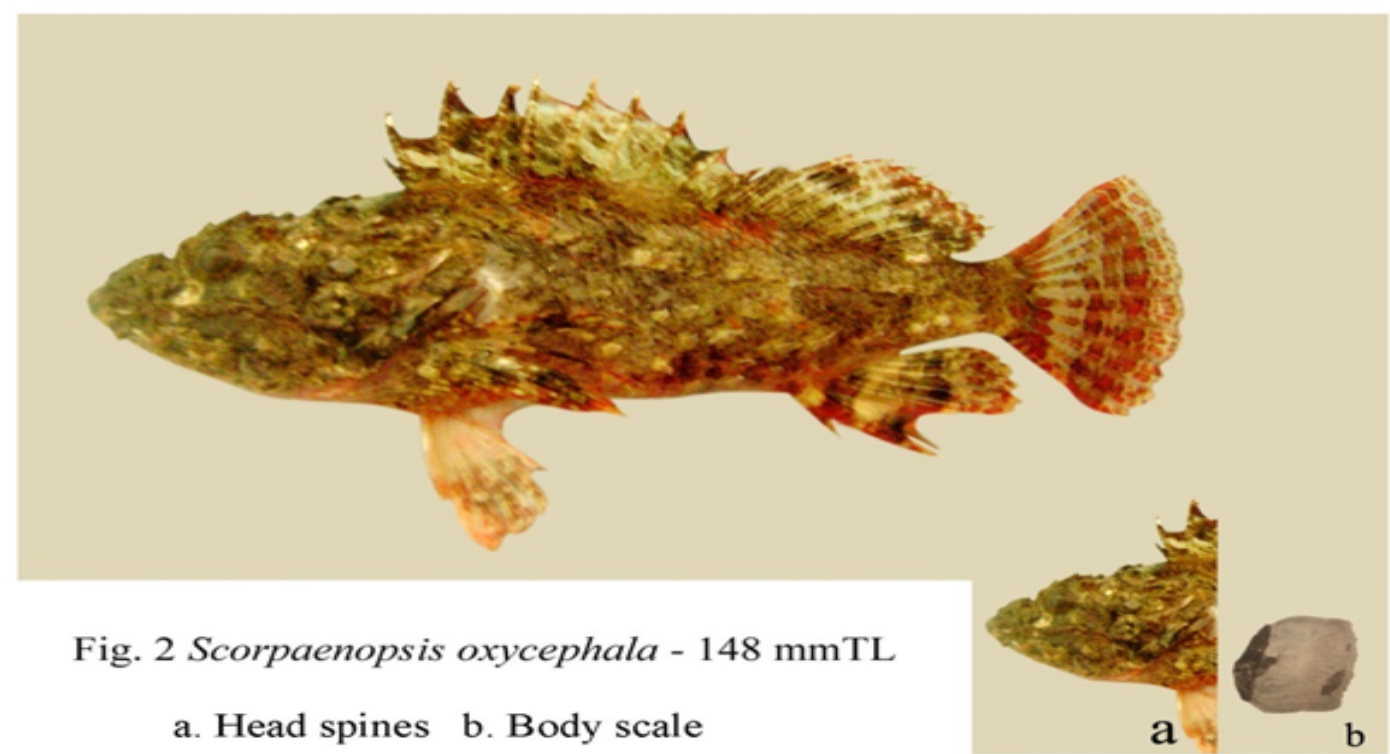

Figure 2: Scorpaena oxycephalus -148mmTL a) Head Spines, b) Body Scale

\section{Meristic characters}

D XII 9-10; A III 5; C 13-15; V I 5; P 1+5-6+11-12=18; Ll 42-45; LlPored scales 22-23; Ltr 7-8+1+20-22; GR; 4-6+1+911=14-18; Pyloric caeca 4-5; Vertebrae 24.

Morphometric data of 22 specimens given in Table-1: Body oblong, slightly compressed; dorsal profile more convex than ventral; dorsal profile of head with slightly slope, with transverse quadrangular depression across occiput and occipital pit very shallow; deep concavity before eyes. Inter orbital slightly groove, narrow, becoming wider with age, coronal ridges low. Mouth large, oblique; lower jaw projecting with symphysial knob; maxilla long, distally broad, reaching to below hind border of eye, under side of lower jaw smooth, without distinct ridges; Eyes directed slightly upward, with elevated supraorbital riges. Snout very long, nostrils close to each other, round; anterior nostril with a multiciliate flap, which has long, posterior one tube like structure, slightly round; its situated a depression before eyes; a smooth median ridge from between posterior nostril to anterior part of interorbital space, flanked by two parallel smooth ridges diverging slightly posteriorly and then converging again and connected behind eye by a convex ridge, the concavity of which is directed towards the shallow occipital pit behind it. Villiform bands of teeth in both jaws, and two or three rows of teeth present, inverted ' $v$ ' shape band of teeth on vomer; palatine teeth absent; patches of teeth on roof and floor of pharynx. Tongue smooth, free, rounded apically. Gill openings wide, gill membrane free from isthmus; pseudobranchiae present; no slit below fourth gill arch. Gill rakers reduced to spiny knobs. Preopeclemedium, slightly rounded; opercular flap pointed, its reaches origin of third dorsal base.

Spines on head well developed; lachrymal stellate, with five radiating spines; two of them extend over maxilla, anterior one directed forward, posterior one backward and downward; sub-orbital bone well developed, with three spines, directed backward, present on lower side of the eye groove; supra orbital ridge broadly expanded laterally over posterior half of eye, the width between tips of postocular spines; tympanic spines about equal in length to postocular spines and well separated from other spines; post orbital with a minute spine; preopercular margin with five spines, upper most one robust, longest, second one small, lower margin of preopercular spines covered with thick skin; supplemental preopercular spine with a small spine, situated base of preopercular spine; cleithral spine strong, directed slightly upward and backward; post orbital spine small, situated on bony elevation; two opercular spines present, upper most longest and parallel to cleithral; upper and lower post temporals small, lower post temporal situated in between pterotic and supracleithral spine; bases of parietal and nuchal spines fused; tympanic spine in pit; post ocular, supraocular and nasal spines present; interorbital ridges poorly developed, originating medial to posterior nostrils and disappearing in posterior interorbital space; a well developed middle interorbital ridge originating between posterior nostrils and reaching to or nearly to midlength of inter orbital; occipital pit absent or very shallow and not separated from interorbital by a ridge; no prominent transverse ridge between parietal spines; coronal spine absent.

Filaments on head; two pairs on snout; a large one above angle of mouth; two on preorbital, posterior one large, cutaneous filaments present on chin and lower jaw and along preopercular edge, along surface of lateral line, thread like tentacles on pectoral fin, body surface and inner side of pectoral fin axil. Small filaments on dorsal fin.Lateral line running high, straightly to caudal peduncle.

Ctenoid scales on most part of the body; small cycloid embedded ctenoid scales on chest, belly and bases of pectorals, pelvic and anal. Minute small embedded scales below eye. No scales on pectoral axil, no scales on opercle between spines.

Origins of dorsal above second half of opercle; origin of dorsal and pelvic same line where as origin of pectoral slightly anterior. Dorsal fin continuous, with notch after penultimate spine; spinous part with eleven spines, soft dorsal with one spine; first dorsal spine very shortest, almost as long as third and more than twice first; increasing in length, third dorsal spine longest, fifth to eleventh dorsal spines gradually smaller; soft rays divided, longer than longest dorsal spine height, soft dor- 
sal slightly rounded; pectorals with rounded edge, reaching to above or vent, upper two to six rays divided, eight to last lower rays fleshy, with pointed tips. Pelvic shorter than pectorals; origin behind that of pectorals. First anal spine shortest, second longest, robust. Rays divided. Caudal fin slightly rounded.

\section{Colour}

Body reddish, clouded with brownish to gray, pale red mottling and having a few blackish spots, lower flanks and ventral side pale. Ventrally pale red with grey mottling; reddish-brown blotch present in inter orbital groove, second to fifth dorsal with dark black oblique band and a dark band transverses from sixth and seventh spines on to the back, many blotches on the fins. A narrow blackish mark often present anteriorly on snout to upper lip; maxilla and lower jaw gray to red-brown streaks. Dorsal fin dusky, soft rays red-brown distally, caudal fin with two to three black bands radiating. Pectoral with black bands, pink and red-brown streaks, undivided pectoral rays spotted. Ventral fin with brown spots.Anal fin with three narrow dark horizontal bands across lower half.Caudal fin with two or three black bands radiating.

\section{Note}

Description, meristic and morphometric data are in good agreement with that of ${ }^{[8-11]}$. In Indian Ocean specimens, pectoral rays 17 and lateral line scales $45^{[10]}$. Present study pectoral rays 18 and lateral line scales 42 - 45. This venomous fish species is typically shallow-water species found on coral reefs and rocky substrata, generally in clear water habitats ${ }^{[1]}$.

It is mainly captured mainly by hand line and shore seine, rarely encountered in trawl catches. A total of 35 specimens of length range 89 - $174 \mathrm{~mm}$ TL were collected during the present study. Spines are venomous. It inhabits clear waters, outer reef slopes and channels from shore to $35 \mathrm{~m}$ depth in areas with mixed rock and coral substrates ${ }^{[1]}$. According to ${ }^{[2]}$ it grows to $36 \mathrm{~cm}$ TL. Earlier Indian records of this species from Madras $^{[8-11]}$ from Andaman and Nicobar Islands. Local Telugu name is "Moragoddu".

\section{Acknowledgements}

The first author very much thankful to University Grants Commission, New Delhi, India and Head of the Marine Living Resources Department, College of Science and Technology, Andhra University for providing facilities during the entire study period

\section{References}

1. Randall, J.E., Eschmeyer, W.N. Revision of the Indo-Pacific scorpionfish genus Scorpaenopsis: with descriptions of eight new species. (2001) Indo-Pac Fishes 34: S1-S79.

2. Froese, R., Pauly, D. (Eds.). FishBase.

3. Russell, P. Description and figures of two hundred fishes: collected at Vizagapatam on the coast of Coramandel. (1803) W. Bulmer \& Co., London 2: S1-S85.

4. Muddula Krisha, N. First record of raggy scorpion fish Scorpaenopsis venosa (Cuvier, 1829) (family: Scorpaenidae) from Visakhapatnam, Central Eastern Coast of India. (2016) Int J Zoology Studies 1(5): S25-S27.

5. Muddula Krishna, N., GovindaRao, V. First record of Rama-Rao's scorpionfish, Scorpaenopsis ramaraoi Randall and Eschmeyer, 2001 (Scorpaenidae) from Visakhapatnam, Andhra Pradesh Coast, India. (2016 ) Fish Taxa 1(2): S84-S88.

6. Eschmeyer, W.N. A new Scorpion fish of the genus Scorpaenodes andS. muciparus(Alcock) from the Indian ocean, with comments on the limits of the genus. (1969) Calif Academ Sci 76: S1-S11.

7. Carpenter, K.E. \& Niem, T.H. (eds). The Living Marine Resources of the Western Central Pacific. (1999) FAO Species Identification Guide for Fisheries Purposes 4: 2069-2790.

8. Day, F. The Fishes of India, London. (1875-1878) XX+778:108 pls. 9. De Beaufort, L.F., Briggs, J.C. Scleoparei, Hypostomides, Pediculati,Plectognathi. Opisthomi, Discocephali, Xenopterygii In The fishes of the Indo Australian Archipelago, (1962) 11. E. J. Brill, Leiden. 481. 10. Smith, M.M., Heemstra, P.C. Scorpaeniformes. Smith's Sea Fishes, ed. M. M.Smith and P. C. Heemstra (1986) Johannesburg: Macmillan South Africa pp: 875-907.

11. Kamala Devi., Rao, D.V. Poisonous and venomous Fishes of Andaman Islands, Bay of Bengal. (2003) Zoological Surv India, Occasional Paper No.211: S1-S71.
Ommega Online Publishers

Journal Title: Journal of Marine Biology and Aquaculture Journal Short Name: J Marine Biol Aquacult
Journal ISSN 2381-0750

E-mail: marinelife@ommegaonline.org

Website: www.ommegaonline.org 